\title{
Some Wood Properties of 10-Year-Old Eucalyptus Camaldulensis Dehnh. in Three Diametric Classes
}

a Universidade Federal de São Carlos, Departamento de ciências ambientais, Campus de Sorocaba, CEP 18052-780, Sorocaba-SP, Brazil

${ }^{\mathrm{b}}$ Instituto Florestal, Rua do Horto, 931, CEP 02340-970, São Paulo-SP, Brazil.

c Universidade Estadual Paulista, Faculdade de Engenharia de llha Solteira, Av. Brasil Sul 56, CEP 15385-000 Campus de llha SolteiraSP, Brazil.

\section{*E-mail: edulongui@gmail.com}

Recebido: 2 de Abril de 2021

Aceito: 17 de Maio de 2021

Publicado online: 20 de Julho de 2021

\section{Algumas Propriedades da Madeira de Eucalyptus camaldulensis Dehnh. com 10 Anos de Idade em Três Classes Diamétricas}

\author{
Bianca M. Lima, ${ }^{a}$ Erick P. Amorim, a Fábio M. Yamaji, ${ }^{a}$ Miguel L.M Freitas, ${ }^{b}$ Juraci A. Barbosa, ${ }^{b}$ José \\ Cambuim, ${ }^{c}$ Darlin U.G. Zaruma, ${ }^{c}$ Mario L. T. de Moraes, ${ }^{c}$ Eduardo L. Longuib,*(D)
}

\begin{abstract}
Multipurpose forests are becoming more frequent, but research on wood is still needed to target it for adequate industrial consumption. However, such determination requires a knowledge of the seed provenance and planting characteristics. Accordingly, this work aimed to characterize the wood quality of 10-year-old E. camaldulensis in three diametric classes for potential use in paper and cellulose production, energy and sawn wood. We studied 10 trees of each diameter class (small, middle, and large) and employed the usual techniques for analyses of each property. E. camaldulensis wood is characterized by an increased percentage of heartwood and a decreased percentage of sapwood as tree diameter increases. Basic density was higher in the larger class; however, this was not directly reflected in better results in other physical properties. For example, volumetric shrinkage was higher in the middle class. Anatomical features-imposed limitations on the presence of fines, and fiber dimensions-imposed limitations on the quality indexes for paper and cellulose, which are important for the industrial use of wood. Wood waste from Eucalyptus camaldulensis could be exploited for bioenergy since its HHV values range from 16425 to $17056 \mathrm{~kJ}_{\mathrm{kg}} \mathrm{kg}^{-1}$. In general, we suggest that trees in the studied spacing and edaphoclimatic conditions do have industrial utility, thus contributing to the forest-based market and reducing the exploitation of native species for this purpose. Based on its wood quality in different diameter classes, E. camaldulensis could benefit from the investment technological strategies to boost genetic gains and obtain better wood properties.
\end{abstract}

Keywords: Plant breeding; reforested wood; wood chemical properties; wood quality

\section{Introduction}

The characterization of technological wood properties allows wood to be assigned to the most suitable uses. Wood characterization should also be carried out considering internal variations, based on the determination of properties in different diameter classes, also allowing assignment to the best technological use, including the classification of sawn wood with similar properties and the homogenization of lots for their commercialization. ${ }^{1}$ Wood is a heterogeneous and anisotropic material, and its characteristics vary in longitudinal and radial directions. ${ }^{2}$ Wood quality parameters can be influenced, for example, in the basal proportion of trunk by root system and at top of trunk by branches. ${ }^{3}$

The structure of a planted or native forest presents wide differences which can be interpreted through the pattern distribution of diameter classes. ${ }^{3}$ Thus, through the technological classification of wood by diameter classes, the ideal interval for cutting trees can be established. This will result in more efficient production and, at the same time, good wood quality.

The formation of forest stands with fast-growing species, such as Eucalyptus spp., is a strategy to increase wood supply and other forest products, while, at the same time, reducing the pressure on native forests. ${ }^{4,5}$ The range of potential products that can be generated from Eucalyptus spp. wood is wide, including, for example, plywood panels, laminated wood, sawn wood, telephone and electric poles, construction anchors, poles, charcoal, cellulose and paper, and structural pieces of buildings with flexible parts. ${ }^{6}$ The success in large cultivable areas of Eucalyptus spp. results from the ability of these species to grow satisfactorily in different edaphoclimatic conditions, existing in different regions of Brazil, and to present widespread use of its wood., ${ }^{7,8}$

In this study, we will investigate Eucalyptus camaldulensis Dehnh. wood, which has a wide occurrence in several natural areas $^{9}$. reports that E. camaldulensis subsp. obtusa is widely distributed between $11^{\circ} \mathrm{S}$ and $36^{\circ} \mathrm{S}$ throughout Australia, except the states of Victoria and 
Tasmania. E. camaldulensis subsp. simulata is a tropical species with more restricted distribution between $15^{\circ} \mathrm{S}$ and $22^{\circ} \mathrm{S}$ in the Australian state of Queensland. The results of provenance tests demonstrated that this species has a high rate of growth, excellent wood properties, tolerance to salinity and alkalinity, and tolerance to drought and frost. ${ }^{10}$ Currently, the commercial use of $E$. camaldulensis is concentrated in the extraction of essential oils used in controlling microbiological agents, such as bacteria, fungi, parasites and viruses. ${ }^{11}$ Essential oils are volatile by the presence of alcohols, ketones, aldehydes, monoterpenes, hydrocarbons and terpenoids in the oil-forming compounds. ${ }^{12}$

Because of these qualities, breeding programs for $E$. camaldulensis have been carried out in Australia, Brazil, China, India, Sri-Lanka, Thailand, the USA, Vietnam and Zimbabwe. ${ }^{13}$ Pioneering work in implementing breeding strategies for $E$. camaldulensis in different countries was started by. ${ }^{14-18}$ These studies also recommended starting with large base populations of seedling lots from natural stands complemented by locally selected material because of uncertainty about the origins of terrestrial breeds and the need to minimize depression from inbreeding. In addition, $E$. camaldulensis clones have been genetically transformed in vitro with success. ${ }^{19}$ Primary and secondary diversity centers have vast genetic resources for E. camaldulensis. However, it is often impossible to trace seeds provenance used for plantations, so the extent of genetic variation available in various regions is uncertain. The wide genetic variability between and within provenances of $E$. camaldulensis has enabled considerable genetic advances for production, justifying its adoption in breeding programs. ${ }^{13}$

Research on wood is still needed before it can be targeted to appropriate industrial consumption. However, such determination requires a knowledge of seeds provenance and planting characteristics. Accordingly, this work aimed to characterize the wood quality of 10-year-old $E$. camaldulensis in three diametric classes for potential use in paper and cellulose production, energy and sawn wood.

\section{Material and Methods}

\subsection{Location and sampling}

The E. camaldulensis seed orchard used in this study was established using within family selection from a provenance and progeny test, which was established from open-pollinated seeds collected at two locations in Australia: Nott's Crossing and Katherine River. ${ }^{20}$ The provenance and progeny test (PP) was planted in April, 1986, in the municipality of Selvíria, Mato Grosso do Sul State $\left(20^{\circ} 20^{\prime} \mathrm{S}, 51^{\circ} 24^{\prime} \mathrm{W}\right.$, elevation $\left.371 \mathrm{~m}\right)$. The site is characterized as moderately flat with a climate classified as $\mathrm{Aw}$, average annual temperature of $24.5^{\circ} \mathrm{C}$, annual average humidity of $64.8 \%$, and average annual rainfall of 1,232 $\mathrm{mm} \cdot{ }^{20}$ The local soil has been classified as oxisoil clay, moderate, hipi-distrophic, kaolinitic, ferric compressed, very deep, and moderately acidic. ${ }^{21}$ In 2008 , from freepollinated seeds collected in a PP test reported by ${ }^{20}$, other plantings were installed in the same place in an area of 3.18 hectares. The experimental design used in both tests was completely randomized blocks, spacing of $3.0 \mathrm{~m}$ x $1.8 \mathrm{~m}$ : a) 136 treatments (progenies), five plants per plot and four replications and b) 133 treatments (progenies), one plant per plot and 20 repetitions. At the age of ten (2018), 40\% of trees were thinned within the treatments / experiments aiming at the formation of a seedlings seed orchards (SSO). ${ }^{22}$ The sampling of the present study was from test $b$.

Based on the highest individual additive genetic value predicted for diameter at breast height (DBH), survival and shape form, using the genetic-statistical Selegen-REML/ BLUP software ${ }^{23}$ was followed to thin genetically inferior trees. Thirty trees were selected, 10 of each diametric class: large 12.03 (14.87) 17.70; middle 8.28 (9.81) 11.49; small 1.43 (4.94) $7.10 \mathrm{~cm}$, minimum (mean) and maximum values, respectively. From smaller tree $(1.43 \mathrm{~cm})$, samples for density and volumetric shrinkage were smaller than those of the other trees. ${ }^{22}$

From each tree, we cut discs from the trunk base (10 $\mathrm{cm}$ thick), and from these, samples close to the bark were obtained to determine heartwood and sapwood percentage and grain orientation, basic density, volumetric shrinkage, anisotropy coefficient, performance, anatomical features, some quality indexes for paper and cellulose based on fiber features, and higher heating value.

\subsection{Heartwood and sapwood percentage and grain} orientation

Eucalyptus camaldulensis wood is characterized by having red to reddish-brown heartwood (after exposure to light and air), so the heartwood and sapwood percentages were initially evaluated by visual observation of disc surfaces (sanded with sandpaper) and analyzed, and relative area calculations were made with a ruler according to the equations below.

$$
\begin{gathered}
H A=\frac{\Pi x(D-2 x A)^{2}}{40000} \\
S A=G-H A \\
H A=100-S A \\
S A=\frac{S A}{G} x 100 \\
G=\frac{\Pi x D^{2}}{40000} \\
H / S=\frac{H A}{S A}
\end{gathered}
$$

Where: HA $=$ Heartwood area $\left(\mathrm{m}^{2}\right) ; \mathrm{D}=$ Average disc diameter $(\mathrm{cm}) ; \mathrm{A}=$ Sapwood thickness $(\mathrm{cm}) ; \mathrm{SA}=$ Sapwood area $\left(\mathrm{m}^{2}\right) ;$ HA\% = Heartwood area percentage; 
SA $\%=$ Sapwood area percentage $; \mathrm{G}=$ Average sectional area $\left(\mathrm{m}^{2}\right) ; \mathrm{H} / \mathrm{S}=$ ratio of heartwood/sapwood.

\subsection{Basic density}

Basic density was determined by the ratio between dry mass and saturated volume. The specimens $(3 \times 2 \times 2 \mathrm{~cm})$ were immersed in water and were considered saturated when they presented constant mass during monitoring in the laboratory. Subsequently, the specimens were dried in an oven at $105^{\circ} \mathrm{C} \pm 2^{\circ} \mathrm{C}$ to obtain the dry mass. The saturation volume was obtained by the hydrostatic balance method. Wood basic density was calculated by the relationship between dry mass and saturated volume in accordance with the Brazilian ${ }^{24}$ as follows:

$$
B D=\frac{D m}{S v}
$$

Where: $\mathrm{BD}=$ Basic density $\left(\mathrm{kg} \cdot \mathrm{m}^{-3}\right) ; \mathrm{Dm}=$ Dry mass $(\mathrm{kg}) ; \mathrm{Sv}=$ saturated volume $\left(\mathrm{m}^{-3}\right)$.

\subsection{Volumetric shrinkage}

Volumetric shrinkage was obtained from the same samples as those used for the basic density. ${ }^{25}$ The samples were saturated in water, their dimensions measured with a caliper (accuracy $=0.001 \mathrm{~mm}$ ) taking three measurements per direction. Then the samples were oven-dried at 105 $\pm 3^{\circ} \mathrm{C}$, followed by determination of the dry volume of each sample. Volumetric shrinkage (as a percentage) is the difference between initial saturated and oven-dried volume divided by initial volume. The anisotropic factor was determined by the relationship between tangential shrinkage and radial shrinkage. ${ }^{26}$ Performance is given as a percentage as follows:

$$
\text { Performace }=\left(\frac{R v}{T v \times V S}\right) \times 100
$$

Where $\mathrm{Rv}=\mathrm{Radial}$ variation; $\mathrm{Tv}=$ Tangential variation; $\mathrm{Vs}=$ Volumetric shrinkage.

\subsection{Anatomical analyses}

We cut small portions of wood from each sample for maceration using Franklin's method ${ }^{27}$. Wood fragments were stained with aqueous safranin and mounted temporarily in a solution of water and glycerin (1:1). Samples of 2 $\mathrm{cm}^{3}$ were softened in boiling water and glycerin (4:1) for 1-2 hours. From these samples, transverse sections $25 \mu \mathrm{m}$ in thickness were obtained with a sliding microtome. Sections were bleached with sodium hypochlorite (60\%), washed thoroughly in water, and stained with $1 \%$ safranin. ${ }^{28}$ Measurements followed the recommendations of the IAWA Committee (1989). ${ }^{29}$ Quantitative data are based on at least 25 measurements for each characteristic from each tree, thus fulfilling statistical requirements for the minimum number of measurements. All anatomical measurements were performed on a microscope (Olympus CX 31) equipped with a camera (Olympus Evolt E330) and a computer with image analyzer software (Image-Pro 6.3).

\subsection{Anatomical ratios for pulp and paper}

From values of length, diameter, lumen diameter, and fiber wall thickness, we calculated the following ratios for pulp and paper: Flexibility coefficient, Wall proportion, Runkel ratio, and Slenderness ratio. ${ }^{30}$

$$
\begin{gathered}
F C=\frac{d}{D} \\
W P=\frac{2 w}{D} \times 100 \\
R R=\frac{2 w}{d} \\
S R=\frac{L}{D}
\end{gathered}
$$

Where: Fiber length is $\mathrm{L}$; fiber diameter is $\mathrm{D}$, lumen diameter is $\mathrm{d}$, and fiber wall thickness is w. We calculated the following ratios for pulp and paper: Flexibility coefficient (FC), Wall proportion (WP), Runkel ratio (RR), and Slenderness ratio (SR). ${ }^{30}$

\subsection{Higher Heating Value (HHV)}

The samples were fragmented into smaller pieces with a hammer and chisel and milled in a micro mill. Higher heating value was determined after thermal rectification with dry samples. To perform the analysis, the isoperibolic method was used with an IKA C200 calorimeter. ${ }^{31}$

\subsection{Energy Density (ED)}

Energy density was calculated as a function of the multiplication of the basic density by the superior calorific power according to the Equation 13.

$$
E D=B D \times H H V
$$

Where: $\mathrm{ED}=$ Energy density; $\mathrm{BD}=$ Basic density; $\mathrm{HHV}=$ Heating Higher Value.

\subsection{Data analyses}

We initially undertook descriptive statistical analyses and used Box Plot graphics to detect outliers. Thus, values 1.5 times higher than the 3 rd quartile and values 1.5 times lower than the 1st quartile were excluded from the analyses. Normality tests were performed to check the distribution of data, and when a normal distribution was not observed, data were square root-transformed. For radial variation, a parametric analysis of variance one-way analyses of variance (ANOVA) was performed. When a significant 
difference was observed, Tukey's test was used to identify pairs of significantly different means.

\section{Results and Discussion}

\subsection{Growth characteristics}

It is common in technological wood characterization to work with the average of technological properties of a given woody species, aiming at its characterization and even recommending its use. The industry, mainly cellulose and paper, takes additional precautions in the use of wood raw material. The anatomical, physical and energy properties among trees and in different diameter classes are always studied and considered when using this material for industrial processing.

For tree height and $\mathrm{DBH}$, values increased from low to high diametric classes. Heartwood percentage increased, while sapwood percentage decreased. The ratio of heartwood to sapwood increased toward the large class. The same pattern of increase from small to large diametric class occurred for basic density. Volumetric shrinkage was higher in the middle class. Anisotropic factor did not vary among the three classes. Performance was higher in the large class and lower in the middle class. Vessel diameter and fiber length increased from small to large diametric classes. Vessel density was higher in the small class, but lower in the large class. Fiber diameter did not differ among classes. Fiber lumen decreased and, consequently, wall thickness increased towards the large class. Flexibility coefficient was higher in the small class, but lower in the large class. Other indexes, including wall fraction, Runkel ratio, and slenderness ratio, were higher in the large class and lower in the small class. HHV was higher in middle and large classes. Energy density increased from small to large class (Table 1).

The average height of 10-year-old Eucalyptus camaldulensis progenies is similar to values reported ${ }^{32}$ with the same age $(14.63 \mathrm{~m})$ and lower than at 19-year-old (17.84 $\mathrm{m}),{ }^{33}$ so individuals have a good performance in growth. The mean diameter at breast height (DBH) of progenies agrees with results ${ }^{32-34} E$. camaldulensis progenies in two locations at 9-year-old $(10.5$ and $13.8 \mathrm{~cm})$ reported mean values between $11.9-15.8 \mathrm{~cm}$ at 10 -year-old in 13 provenances. These authors also explain that growth in diameter depends on water availability, temperature and genetics provenance.

\subsection{Relationship Heartwood and sapwood}

The ratio of heartwood to sapwood differed among the diameter classes (Table 1). The proportion of heartwood in the large class was greater than that in the small and middle classes, whereas the proportion of sapwood was greater in the small and middle classes. The use of treated wood, or cellulose production, will give preference to higher proportions of sapwood. Heartwood is less permeable than
Table 1. Comparison among wood properties of 10-year-old Eucalyptus camaldulensis in three diametric classes

\begin{tabular}{lccc}
\hline & Small & Middle & Large \\
\hline TH $(\mathrm{m})$ & $9.0 \mathrm{c}$ & $15.2 \mathrm{~b}$ & $20.3 \mathrm{a}$ \\
DBH $(\mathrm{cm})$ & $49 \mathrm{c}$ & $9.8 \mathrm{~b}$ & $14.8 \mathrm{a}$ \\
HW $(\%)$ & $50 \mathrm{c}$ & $69 \mathrm{~b}$ & $75 \mathrm{a}$ \\
$\mathrm{SW}(\%)$ & $50 \mathrm{a}$ & $31 \mathrm{~b}$ & $25 \mathrm{c}$ \\
$\mathrm{H} / \mathrm{S}$ & $1.0 \mathrm{c}$ & $2.3 \mathrm{~b}$ & $3.0 \mathrm{a}$ \\
$\mathrm{BD}\left(\mathrm{kg} \cdot \mathrm{m}^{-3}\right)$ & $425 \mathrm{c}$ & $504 \mathrm{~b}$ & $546 \mathrm{a}$ \\
VS $(\%)$ & $23.2 \mathrm{~b}$ & $27.9 \mathrm{a}$ & $23.5 \mathrm{~b}$ \\
AF & $1.4 \mathrm{a}$ & $1.5 \mathrm{a}$ & $1.5 \mathrm{a}$ \\
$\mathrm{P}$ & $2.7 \mathrm{ab}$ & $2.4 \mathrm{~b}$ & $2.9 \mathrm{a}$ \\
VD $(\mu \mathrm{m})$ & $77 \mathrm{c}$ & $87 \mathrm{~b}$ & $98 \mathrm{a}$ \\
Vd $\left(\mathrm{n}^{\circ} \mathrm{mm} \mathrm{m}^{-2}\right)$ & $18 \mathrm{a}$ & $13 \mathrm{~b}$ & $10 \mathrm{c}$ \\
FL $(\mu \mathrm{m})$ & $1575 \mathrm{c}$ & $1701 \mathrm{~b}$ & $1844 \mathrm{a}$ \\
FD $(\mu \mathrm{m})$ & $14.8 \mathrm{a}$ & $14.4 \mathrm{a}$ & $14.1 \mathrm{a}$ \\
FL $(\mu \mathrm{m})$ & $8.4 \mathrm{a}$ & $7.0 \mathrm{~b}$ & $5.7 \mathrm{c}$ \\
FWT $(\mu \mathrm{m})$ & $3.1 \mathrm{c}$ & $3.7 \mathrm{~b}$ & $4.2 \mathrm{a}$ \\
FC & $56.27 \mathrm{a}$ & $47.40 \mathrm{~b}$ & $39.75 \mathrm{c}$ \\
WP $(\%)$ & $43.72 \mathrm{c}$ & $52.59 \mathrm{~b}$ & $60.24 \mathrm{a}$ \\
RR & $0.83 \mathrm{c}$ & $1.23 \mathrm{~b}$ & $1.73 \mathrm{a}$ \\
SR & $110.08 \mathrm{c}$ & $123.71 \mathrm{~b}$ & $135.37 \mathrm{a}$ \\
HHV $\left(\mathrm{kJ} . \mathrm{kg}^{-1}\right)$ & $16425 \mathrm{~b}$ & $17153 \mathrm{a}$ & $17056 \mathrm{a}$ \\
ED $\left(\mathrm{kJ} . \mathrm{m}^{3}\right)$ & $7757 \mathrm{c}$ & $10081 \mathrm{~b}$ & $11183 \mathrm{a}$ \\
\hline
\end{tabular}

$\mathrm{TH}=$ tree height; $\mathrm{DBH}=$ diameter at breast height; $\mathrm{HW}=$ heartwood percentage; $\mathrm{SW}=$ sapwood percentage $; \mathrm{BD}=$ basic density; $\mathrm{VS}=$ Volumetric shrinkage; $\mathrm{AF}=$ anisotropic factor; $\mathrm{P}=$ performance; $\mathrm{VD}=$ vessel diameter; $\mathrm{Vd}=$ vessel density; $\mathrm{FL}=$ fiber length $; \mathrm{FD}=$ fiber diameter; $\mathrm{FL}=$ fiber lumen diameter; FWT = fiber wall thickness; $\mathrm{FC}=$ flexibility coefficient; $\mathrm{WP}=$ wall fraction $; \mathrm{RR}=$ Runkel ratio $; \mathrm{SR}=$ slenderness ratio

sapwood which would involve more difficulties in drying and absorbing preservatives, in addition to increasing the consumption of alkali, which would reduce the yield in cellulose since extractives content is also greater. ${ }^{35}$

In charcoal production, $\mathrm{H} / \mathrm{S}$ ratio affects the initial stage of processing, which is characterized by wood drying. Wood from trees with large diameter would require more time to dry and enter into the combustion process. Considering only drying time,${ }^{36}$ report that lower $\mathrm{H} / \mathrm{S}$ ratio would be adequate. This occurs because high heartwood content may make it difficult to dry the wood since heartwood is impermeable, mainly owing to vessel obstruction by tyloses, making it difficult to transport water from pith to bark. ${ }^{37}$ Sapwood dries faster, while heartwood is moist and slow to remove. Under these conditions, gas vapor pressure increases inside the anatomical elements, and the cells may rupture, culminating in a more fragile and brittle coal.

Lower $\mathrm{H} / \mathrm{S}$ ratio observed in small and middle classes are required for fines production since carbonization occurs from the surface to the interior of a wood piece, resulting in the release of gases originating during the process. ${ }^{36}$ These gases must be released, and for this to happen, disruption may occur, mainly in parenchymal cells, which have thinner cell walls and are, therefore, less rigid. Thus, a high 
percentage of heartwood will result in a proportionately higher obstructive pathway and, consequently, higher content of fines. However, this means lower reactivity power of coal. The proportion of fines resulting from wood combustion is dependent on the initial carbonization temperature, percentage of obstructed vessels, initial wood humidity, and piece diameter.

The H/S ratio values in diameter classes were higher than those ${ }^{38}$ who evaluated wood quality of 10 -year-old Eucalyptus camaldulensis from an agrosilvopastoral plantation, varying from 1.7-2.0. However, it is known that values based on ratios are largely dependent on edaphoclimatic, topographic and spacing conditions. ${ }^{39}$ Therefore, since the wood studied came from a managed system, we suggest a direct influence on technological wood properties. ${ }^{38}$

\subsection{Quality of wood to produce paper and cellulose, energy and sawn wood}

Wood basic density is a complex property resulting from the combination of several factors, e.g., fiber dimensions, particularly wall thickness, vessel diameter and vessel density, as well as $\mathrm{H} / \mathrm{S}$ ratio. ${ }^{40}$ We observed that the large diameter class had higher basic density owing to its high proportion of heartwood, longer fibers with thicker walls and smaller lumen, i.e., low proportion of liquids in the intracellular spaces. The opposite effect was observed in the small class where basic density is lower as a result of high vessel density and shorter fibers with thinner walls (Table 1).

Basic density values indicate that wood quality in small and middle diameter classes has desirable characteristics suitable for the paper and cellulose industry. Pulp and paper producers using products from Eucalyptus forests prefer wood density values between 400 to $500 \mathrm{~kg} . \mathrm{m}^{-3}$. Wood density less than $400 \mathrm{~kg} \cdot \mathrm{m}^{-3}$ in the pulp and paper industry leads to reduced yield, greater consumption of reagents and a high content of tailings, while density at $550 \mathrm{~kg} . \mathrm{m}^{-3}$ presents greater difficulties in chopping logs, which leads to wear of the chopping knives. ${ }^{41}$

Volumetric shrinkage was higher in the middle diametric class. In general, Eucalyptus spp. have high volumetric shrinkage, especially those from fast-growing trees. Evaluating volumetric shrinkage from seven Eucalyptus clones, reported values of 15.9 to $27.2 \%$, a range of variation that fits the classes of small and large diameter for $E$. camaldulensis. ${ }^{42}$ However, although the middle class has higher volumetric shrinkage, it inevitably leads to a greater propensity for the occurrence of defects in the drying phase. Furthermore, because of sudden variations in hygroscopic equilibrium humidity, drying techniques must be adopted in every wood piece in order to homogenize wood moisture and subsequently avoid defects in the processing parts.

The anisotropic factor is the relationship between tangential and radial retractability. The ideal situation for wood use, however rarely found, would be one in which the tensions arising from anisotropy would cancel each other out in the direction from which retractability first manifested, with values closer to 1 . The importance of this index involves the propensity of wood to crack and warp during dimensional changes caused by hygroscopic variation when the distance from the ideal unit (1) increases. Eucalyptus species are known to have high anisotropy because they are a fast- growing species. Thus, our results in three diameter classes show broader satisfaction for wood use at a younger age.

Wood classification criteria for the anisotropic factor: 1.2-1.5, excellent; $1.5-2.0$, normal; and above 2.0 , poor. ${ }^{43}$ According to their scoring system, E. camaldulensis wood would be considered normal to excellent, based on dimension class. It would be very stable, would find it useful for building fine furniture, frames, shelves, tables and uses that allow small bends. ${ }^{44,45}$

Closely related to basic density, wood anatomical features define wood quality, allowing it to be classified for the desired uses, e.g., paper and energy. ${ }^{46-49}$

Paper and cellulose industry prefers to use Eucalyptus wood up to six years of age since the fibers can be collapsed and hydrated more easily than can be done in older woods. ${ }^{50}$ Thus, the use of older trees should be avoided, as adult wood tends to have a higher extractives content and mineral salts, in addition to higher density, which will decrease water permeability, making treatment for paper production more difficult. However, in the absence of production control over different diameter classes, the chips are mixed, and the batches are homogenized, making it difficult to differentiate wood quality for this purpose. Therefore, proposed a classification still used today by paper and cellulose producers. ${ }^{51}$ It is a five-point classification known as the Runkel Index, as follows: fibers classified in group I (up to $0.25)$ are considered excellent for paper, in group II ( 0.25 $0.50)$, very good, in group III (0.5-1.0), good, in group IV (1.0-2.0), regular, and in group $\mathrm{V}$ (above 2.0), they should not be used for paper production based on the low degree of collapse. Based in classification system, in our study, the small class is considered good (0.83), and the middle and large classes are considered regular. ${ }^{51}$

For all diameter classes in our study, wall fraction above $40 \%$ is recommended..$^{51}$ In practice, producers admit that fibers will be more rigid and difficult to collapse when the wall fraction is higher than $40 \%$ and, thus, produce a looser mesh paper without much connection between fibers. As a result, the corresponding papers are more porous, bulky, rough and absorbent. ${ }^{51}$ In our study, small class has a value closer to what is considered ideal by the paper and cellulose industry $(43.72 \%)$. This can be attributed to the shorter fiber as it affects some properties, such as tear resistance and resistance to folds. However, short fibers favor paper production with a more homogeneous pore size distribution, benefiting ink absorption and, consequently, printing. ${ }^{41}$ 
Flexibility coefficient is related to the degree of collapse that fibers undergo during the papermaking process such that the higher the value, the greater the resistance to breakage and the lower the tensile strength. Thus, in refined short fiber pulps, more intersections and areas of connections available per unit of mass will be found. ${ }^{52}$ This is true in the small and middle classes which have greater resistance to rupture and low tensile strength relative to the large diameter class reported values between $0.50-1.00$, as observed in the small class, allow the fibers to be classified as flexible, which, when intertwined, tend to form highly resistant paper. Large diametric classes, according to the classification $\mathrm{of}^{53}$, are considered to exhibit medium interlacing of fiber, requiring greater amounts of reagents to be used for greater brightness of the cellulose pulp and greater compaction and union of fibers. However, ${ }^{54}$ mention that species with flexibility coefficient values up to 2.00 , as observed in $E$. camaldulensis, are suitable for production of paper with high mechanical resistance and can be used for papers used in writing, printing and packaging.

We observed differences in slenderness ratio among diameter classes, but all were considered satisfactory for paper production. However, the lower this index, the greater the resistance. The large diameter class has a value of 135.37, the highest value observed for this ratio. This occurred because of the presence of high heartwood percentage, longer fibers with thicker walls and smaller lumen. Thicker-walled fibers present greater defibrillation during the refining process, decreasing tensile strength. ${ }^{41}$

A higher calorific value in wood with higher density can be expected, but in our samples, this commonly known pattern was not observed, as the large diametric class presents higher wood density, but HHV did not differ between the large and middle classes. However, energy density was proportional to basic density increase in three diameter classes, inferring that the higher the density, the greater the energy amount stored per cubic meter. Therefore, this characteristic is very important in choosing species for direct wood burning. In addition, the higher wood density results in greater densities and resistance of charcoal, as well as a greater quantity of hanged mass, reducing production costs and increasing productivity of coal units (UPCs) and in the blast furnaces..$^{55}$

Densities between 400 and $560 \mathrm{~kg} \cdot \mathrm{m}^{-3}$; thus, whole log in different diameter classes of E. camaldulensis can be used for energy production since all values are within the aforementioned range ${ }^{56}$ Emphasize that Eucalyptus spp. are widely used in Brazil for bioenergy purposes and that these values are largely dependent on edaphoclimatic conditions, spacing, as well as a combination of factors, such as fiber dimensions, heartwood and sapwood ratio.

A study was carried out in Brazil evaluating the energy quality of $E$. benthamii, E. dunnii, E. grandis, $E$. saligna, and $E$. urograndis, all widely improved and used in Brazil for energy use at age 7. The study shows HHV

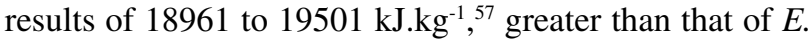
camaldulensis. Genetic variation for energy production, growth characteristics and wood quality of 23 hybrids of 8.5-year-old Eucalyptus in China. ${ }^{58}$ They reported HHV from 10962 to $15815 \mathrm{~kJ} \cdot \mathrm{kg}^{-1}$, lower than that observed in our study, allowing us to infer that seeking strategies and investing in genetic improvement through hybridization of E. camaldulensis in Brazil can bring benefits in terms of improving energy potential and wood quality since wood adapts well to Brazilian edaphoclimatic characteristics.

Brazilian forestry market admits that HHV values ranging from 16500 to $18000 \mathrm{~kJ}^{\mathrm{kg}}{ }^{-1}{ }^{59}$ could indicate exploitation of waste for bioenergy, suggesting the potential of $E$. camaldulensis wood for this purpose, i.e., HHV ranges

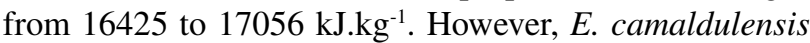
has the potential to be improved in order to achieve gains and boost energy production and subsequently reduce exploitation of native wood for energy production.

\section{Conclusion}

Eucalyptus camaldulensis wood at 10 years is characterized by an increase in percentage of heartwood and a decrease in sapwood as tree diameter increases. The basic density was higher in the larger class; however, this was not directly reflected in better results in other physical properties such as VS, which was higher in the middle diameter class. Anatomical features impose limitations on the presence of fines, and fiber dimensions impose limitations on the quality indexes for paper and cellulose, which are important for the industrial use of wood. HHV values ranging from 16500

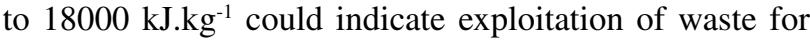
bioenergy, suggesting the potential of E. camaldulensis wood for this purpose, i.e., HHV ranges from 16425 to

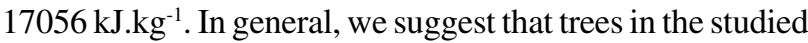
spacing and edaphoclimatic conditions have the potential to serve the wood-producing industry, contribute to the forestbased market, and reduce the exploitation of native species for this purpose. Wood quality in different diameter classes shows that E. camaldulensis has potential for investment in the technology required to make improvements to boost genetic gains and obtain better wood properties.

\section{Acknowledgments}

The authors thank Sonia Regina Godoi Campião (Forestry Institute - IF) for laboratory assistance. We also thank the CNPq (National Council for Scientific and Technological Development) for the research scholarship to Bianca de Melo Lima. Erick Phelipe Amorim was supported by a research scholarship from the Coordenação de Aperfeiçoamento de Pessoal de Nível Superior - Brazil (CAPES) - Finance-Code 001. Researchers Eduardo L. Longui, Fábio M. Yamaji, 
Mário L.T. Moraes, and Miguel L.M. Freitas were supported by a research scholarship from the Conselho Nacional de Desenvolvimento Científico e Tecnológico (CNPq).

\section{References}

1. Valente, B. M. R. T.; Evangelista, W. V.; Silva, J. C.; Della Lucia, R. M.; Variabilidade radial e longitudinal das propriedades físicas e anatômicas da madeira de angico-vermelho. Scientia Forestalis 2013, 41, 485. [Link]

2. Rios, P. D.; Vieira, H. C.; Pereira, G. F.; Turmina, E.; Nicoletti, M. F.; Variação radial e longitudinal da densidade básica da madeira de Pinus patula. Pesquisa Florestal Brasileira 2018, 38, 1. [CrossRef]

3. Orellana, B. B. M. A.; Do Valle, A. T.; Gonçalves, J.; Guedes, M. C.; Produtividade energética da madeira de Tachigalis vulgaris por classe diamétrica em plantios experimentais na Amazônia. Nativa 2018, 6, 773. [CrossRef]

4. Ferreira, D. H. A. A.; Leles, P. S. S.; Neto, S. O. N.; Paula, T. R.; Crescimento e produção de Eucalipto na região do médio Paraíba do Sul, RJ. Floresta e Ambiente 2017, 24, e00131315. [CrossRef]

5. Lahr, F. A. R.; Nogueira, M. C. J. A.; De Araújo, V. A.; Christoforo, A. L.; Wood utilization of Eucalyptus grandis in structural elements: densities and mechanical properties. Engenharia Agrícola 2018, 38, 642. [CrossRef]

6. Lahr, F. A. R.; De Macedo, L. B.; Balanco, G. G.; Santos, N. A.; Christoforo, A. L.; Reparação em vigas de Eucalyptus usando peças de Pinus tratado com CCB. Revista Portuguesa de Engenharia de Estruturas 2017, 3, 29. [Link]

7. Lima, P. A. F.; Dermachi, J.; Silva, M. F.; Moraes, M. D. A.; Caldas, D. J.; Sette-Junior, C. R.; Qualidade da madeira de eucalipto para aplicação como mourão tratado. Revista de Ciências Agrárias 2019, 42, 509. [CrossRef]

8. Brito, A. S.; Vidaurre, G. B.; Oliveira, Da Silva, J. G. M.; Oliveira, R. F.; Dias-Junior, A. F.; Arantes, M. D. S.; Moulin, J. C.; Valin, M.; Siqueira, L.; Zauza, E.A. V.; Interaction between planting spacing and wood properties of Eucalyptus clones grown in short rotation. Iforest - biogeosciences and forestry 2021, 14, 12. [CrossRef]

9. Flores, T. B.; Alvares, C. A.; Souza, V.; Stape, J. L.; Eucalyptus in Brazil - Climatic Zoning and Identification Guide, 1st. ed., IPEF - Instituto de Pesquisas e Estudos Florestais: Piracicaba, 2018.

10. Eldridge, K.; Davidson, J.; Harwood, C.; Wyk, G. V.; Eucaplyptus domestication and breeding, 1st. ed., Oxford University Press: Oxford, 1993.

11. Ghasemian, A. Slami, M.; Hasavand, F.; Bozorgi, H.; A1Abodi, H. R.; Eucalyptus camaldulensis properties for use in the eradication of infections. Comparative Immunology, Microbiology, and Infectious Diseases 2019, 65, 234. [CrossRef]

12. Lee, K. G.; Shibamoto, T.; Antioxidant activites of volatile components isolated from Eucalyptus species. Journal Science Food Agriculture 2001, 81, 1573. [CrossRef]

13. Rojas-sandoval, J.; Acevedo-Rodríguez, P.; Naturalization, and invasion of alien plants in Puerto Rico and the Virgin Islands. Biological Invasions 2015, 17, 149. [CrossRef]

14. Barnes, R. D.; In Provenance and Genetic Improvement Strategies in Tropical Forest Trees; Barnes, R. D.; Gibson, G. L., eds.; Commonwealth Forestry Institute: Oxford, 1984, chap. 6.
15. Raymond, C. A.; Eucalyptus camaldulensis - a breeding plan for Thailand. Available in: <https://www.cabi.org/isc/ datasheet/22596> Accessed on: 27 march 2021.

16. Davidson, J.; Domestication and breeding programme for Eucalyptus in the Asia-Pacific region. Regional Project on Improving Productivity of Man-Made Forests Through Application of Technological Advances in Tree Breeding and Propagation (RAS/91/004-FORTIP). FAO of the United Nations 1993, 23, 1. [Link]

17. Doran, J. C.; Matheson, A. C.; Genetic parameters, and expected gains from selection for monoterpene yields in Petford Eucalyptus camaldulensis. New Forests 1994, 8, 155. [CrossRef]

18. Gurgel-garrido, L. M. A.; Siqueira, A. C .M. F.; Cruz, S. F.; Romanelli, R .C.; Ettori, L. G.; Crestana, C. S. M.; Silva, A. A.; Morais, E.; Zanatto, A. C. S.; Sato, A. S.; Programa de melhoramento genético florestal do Instituto Florestal. IF Série Registros 1997, 18, 1. [Link]

19. Thanananta, N.; Vuttipongchaikij; S.; Apisitwanich, S.; Agrobacterium-mediated transformation of a Eucalyptus camaldulensis $\times$ E. tereticornis hybrid using peeled nodal-stem segments with yeast HAL2 for improving salt tolerance. New forests 2018, 49, 311. [CrossRef]

20. Gonzaga, J. M. S.; Manoel, R. O.; Sousa, A. C. B.; Souza, A. P.; Moraes, M. L. T.; Freitas, M. L. M.; Sebben, A. M.; Pollen contamination and nonrandom mating in a Eucalyptus camaldulensis Dehnh seedling seed orchard. Silvae Genetica 2016, 65, 1. [Crossref]

21. Site Embrapa Solos. Available in: <https://www.embrapa.br/ solos/sibcs $>$ Accessed on: 28 march 2021.

22. Zaruma, D. U. G.; Tese de doutorado, Universidade Estadual Paulista, 2020. [Link]

23. Resende, M. D. V.; Selegen-reml/blup: sistema estatístico e seleção genética computadorizada via modelos lineares mistos. Available in: <https://www.scienceopen.com/document?vid=984386783de5-45d3-96f3-a2552b9c9f2a >. Accessed on: 28 march 2021.

24. Site ABNT/NBR 11941 (2003) Associação Brasileira de Normas Técnicas. Determinação da densidade básica da madeira. Available in: <https://www.abntcatalogo.com.br/norma. aspx?ID=002494 >. Accessed on: 28 março 2021.

25. Site ABNT/NBR 7190 (1997) Associação Brasileira de Normas Técnicas. Projeto de estruturas de madeira. Available in: $<\underline{\text { https: // }}$ www.abntcatalogo.com.br/norma.aspx?ID=3395 >. Accessed on: 28 março 2021.

26. Eufrade-JR, H. J.; Ohto, J. M.; Palma, H. A. L.; Ballarin, A. W.; Potential of rubberwood (Hevea brasiliensis) for structural use after the period of latex extraction: a case study in Brazil. Journal Wood Science 2015, 61, 384. [CrossRef]

27. Berlyn, G. P.; Miksche, J. P.; Botanical microtechnique and cytochemistry, 1st. ed., The Iowa University Press: Iowa, 1976.

28. Johansen, D. A.; Plant Microtechnique, 1st. ed., McGraw-Hill Book Company Inc: New York, 1940.

29. Site Committee-IAWA. Available in: $<$ https://www.iawa-website. org/uploads/soft/Abstracts/01 IAWA-Softwood List.pdf $>$. Accessed on: 11 june 2021.

30. Pirralho, M.; Flores, D.; Sousa, V.B.; Quilhó, T.; Knapic, S.; Pereira, H.; Evaluation on paper making potential of nine Eucalyptus species based on wood anatomical features. Industrial Crops and Products 2014, 54, 327. [CrossRef] 
31. Site ASTM International. Available in: <encurtador.com.br/ dlwMZ>. Accessed on: 11 june 2021.

32. Tanvir, M.A.; Siddiqui, M. T.; Shah, A. H.; Growth and Price Trend of Eucalyptus camaldulensis in Central Punjab. International Journal of Agriculture \& Biology 2002, 4, 344. [Link]

33. Moraes, M. A.; Zanatto, A. C. S.; Freitas, M. L. M.; Variação genética para caracteres silviculturais em progênies de procedente de Victoria River, Austrália. Revista do Instituto Florestal 2007, 31, 229. [Link]

34. Varghese, M.; Ravi, N.; Kamalakannan, R.; Harwood, C. E.; Effect of silvicultural treatments on growth, fertility and capsule traits in seedling seed orchards of Eucalyptus camaldulensis and Eucalyptus tereticornis. New Forests 2009, 37, 99. [Crossref]

35. Miranda, I.; Gominho, J.; Pereira, H.; Variation of heartwood and sapwood in 18-year-old Eucalyptus globulus trees grown with different spacings. Trees 2009, 23, 367. [CrossRef]

36. Pereira, B. L. C.; Oliveira, A. C.; Carvalho, A. M. M. L.; Carneiro, A. C. O.; Vital, B. R.; Santos, L .C. Correlações entre a relação Cerne/Alburno da madeira de eucalipto, rendimento e propriedades do carvão vegetal. Scientia Forestalis 2013, 41, 217. [Link]

37. Oliveira, A. C.; Carneiro, A. C. O.; Pereira, B. L. C.; Vital, B. R.; Carvalho, A. M. M. L.; Trugilho, P. F.; Damásio, R. A. P.; Otimização da produção de carvão vegetal por controle de temperaturas de carbonização. Revista Árvore 2013, 37, 557. [CrossRef]

38. Evangelista, W. V.; Dissertação de Mestrado, Universidade Federal de Viçosa, 2007. [Link]

39. Almeida, M. N. F.; Vidaurre, G. B.; Pezzopane, J. E. M.; Lousada, L. P. C.; Silva, M. E. C. M.; Câmara, A.; Rocha, S. M. G. R.; Oliveira, J. C. L.; Campoe, O. C.; Carneiro, R. L.; Alvares, C. A.; TommazeloFilho, M.; Figueiredo, F. M.; Oliveira, R. F.; Heartwood variation of Eucalyptus urophylla is influence by climatic conditions. Forest Ecology Management 2020, 458, 117743. [CrossRef]

40. Vidrano, B. R. A.; Pedrazzi, C.; Almeida, D. P.; Gomes, F. J. B.; Baldin, T.; In O meio Ambiente Sustentável; Pacheco, J. T. R.; Kawanish, J. Y.; Pacheco, M. Z., eds.; Atena: Ponta Grossa, 2019, chap. 9.

41. Dias, O. A.; Simonelli, G.; Qualidade da madeira para a produção de celulose e papel. Enciclopédia Biosfera, 2013, 9, 3632. [Link]

42. Oliveira, J. T. S.; Tomazzelo-Filho, M.; Fiedler, N. C.; Avaliação da retratibilidade de sete espécies de Eucalyptus. Revista Árvore, 2010, 34, 5, 929. [CrossRef]

43. Durlo, M. A.; Marchiori, J. N. C.; Tecnologia da madeira: retratibilidade, 1st ed., Centro de Pesquisas Florestais: Santa Maria, 1992.

44. Klitzke, R. J.; In Tecnologias aplicadas ao setor madeireiro; Oliveira, J. T. S.; Fiedler, N. C.; Nogueira, N., eds.; Suprema: Jerônimo Monteiro, 2007, chap. 7.

45. Nock, H. P.; Ritcher, H. G.; Burger, L. M.; Tecnologia da madeira, 1st ed., UFPR: Curitiba, 1975.

46. Duong, D. V.; Hasegawa, M.; Matsumura, J.; The relations of fiber length, wood density, and compressive strength to ultrasonic wave velocity within stem of Melia azedarach. Journal of the Indian Academy of Wood Science 2019, 16, 1. [CrossRef]
47. Gonzalez, J. C.; dos Santos, G. L.; Silva-Junior, F. G. S.; Martins, I. S.; Costa, J. A.; Relações entre dimensões das fibras e de densidade da madeira ao longo do tronco de Eucalyptus urograndis. Scientia forestalis 2014, 42, 81. [Link]

48. Lima, I. L.; Longui, E. L.; Garcia, R.; Luca, E. F.; Silva-Júnior; Florsheim, S. M.; Propriedades da madeira de Eucalyptus umbra R.T. Baker em função do diâmetro e da posição radial da tora. Floresta e Ambiente 2011, 18, 289. [CrossRef]

49. Trevisan, R.; Rosa, M.; Haselein, C. R.; Santini, E. J.; Gatto, D. A.; Dimensões das fibras e sua relação com a idade de transição entre o lenho juvenil e adulto de Eucalyptus grandis W. Hill ex. Maiden. Ciência floresta 2017, 27, 1385. [CrossRef]

50. Barrichelo, L. E. G.; Brito, J. O.; A madeira das espécies de eucalipto como matéria-prima para a indústria de celulose e papel. Available in: <https://biblioteca.incaper.es.gov.br /busca $? \mathrm{~b}=\mathrm{ad} \& \mathrm{id}=3643 \&$ biblioteca $=$ vazio $\&$ busca $=$ autoria: $\% 22$ BRITO,\%20J.\%20O.\%22\&qFacets=autoria:\%22BRITO, $\% 20$ $\mathrm{J} . \% 200 . \% 22 \&$ sort $=\&$ paginacao $=\mathrm{t} \&$ paginaAtual $=1>$. Accessed on: 28 march 2021.

51. Foelkel, C. E. B.; Eucalyptus online book e newsletter. Available in: <https://www.eucalyptus.com.br/>Access on: 28 march 2021

52. Nisgoski, S.; De Muniz, G. I. B.; Trianoski, R.; De Matos, J. L. M.; Venson, I.; Características anatômicas da madeira e índices de resistência do papel Schizolobium parahyba (Vell.) Blake em plantio experimental. Scientia Forestalis 2012, 40, 203. [Link]

53. Bektas, I.; Tutus, A.; Eroglu, H.; A study of the suitability of Calabrian Pine (Pinus burtia, Jen) for pulp and paper manufacture. Turkish Journal of Agriculture and Forestry 1999, 23, 589. [Link]

54. Saikia, S. N.; Goswami, T.; Ali, F.; Evaluation of pulp and paper making characteristics of certain fast-growing plants. Wood Science and Technology 1997, 31, 467. [CrossRef]

55. Protásio, T. P.; Couto, A. C.; dos Reis.; Trugilho, P. F.; Seleção de clones de Eucalyptus para a produção de carvão vegetal e bioenergia por meio de técnicas univariadas e multivariadas. Scientia Forestalis 2013, 41,15. [Link]

56. Carneiro, A. C. O.; Castro, A. F.M.; Castro, R. V. O.; Dos Santos, R. C.; Ferreira, L. P. Damásio, R. A. P.; Vital, B. R. Potencial energético da madeira de Eucalyptus sp. em função da idade e de diferentes materiais genéticos. Revista Árvore 2014, 38, 375. [Crossref]

57. Simetti, R.; Bonduelle, G. M.; Da Silva, D. A.; Mayer, S. L. S.; Souza, H. P.; De Muniz, G. I. B. Production of biomass and energy stock for five Eucalyptus species. Revista Ciência da madeira 2018, 9, 30. [CrossRef]

58. Wu, S.; Zhu, H.; Xu, Z.; Lu, G. C.; Chen, P.; Song, P.; Guo, W.; Genetic variation and genetic gain for energy production, growth traits and wood properties in Eucalyptus hybrid clones in China. Australian Forestry 2017, 80, 57. [CrossRef]

59. Menucelli, J. R.; Amorim, E. P.; Freitas, M. L. M.; Zanata, M.; Cambuim, J.; Moraes, M. L. T.; Yamaji, F. M.; Silva-Junior, F. G.; Longui, E. L. Potential of Hevea brasiliensis Clones, Eucalyptus pellita and Eucalyptus tereticornis Wood as Raw Materials for Bioenergy Based on Higher Heating Value. Bioenergy Research. 2019, 12, 992. [CrossRef] 